Tarih Kültür ve Sanat Araştırmaları Dergisi

Revue des Recherches en Histoire Culture et Art

مجلة البحوث التاريخية و الثقافية والفنية
Vol. 7, No. 2, June 2018

Copyright (C) Karabuk University

http://kutaksam.karabuk.edu.tr

\title{
DOI: 10.7596/taksad.v7i2.1501
}

Citation: Gülhan, G. (2018). Tarihi Çevrede Ulaşım Stratejisi ve Illkeleri: Şirince Örneği. Journal of History Culture and Art Research, 7(2), 475-490. doi:http://dx.doi.org/10.7596/taksad.v7i2.1501

\section{Tarihi Çevrede Ulaşım Stratejisi ve ilkeleri: Şirince Örneği}

\author{
Transportation Strategy and Principles in Historical Environment: The Example of Sirince
}

\section{Görkem Gülhan ${ }^{1}$}

\begin{abstract}
Throughout history, cities and transportation have been interacting. The types and volume of this interaction have diversified with the change over time in the types of transportation, vehicles and spaces. This relationship between transportation characteristics and settlement patterns has been shaped by the social, spatial and economic characteristics of history, and in this context has created new and different opportunities for interaction. Rapid and violent enlargement in cities after the industrial revolution and the establishment of links for new scales related to transport axes have separated street patterns in historical environments from the new urban dynamics. Historical environments could not be fully analyzed within this scale, and the applications directed towards the historical environment were designed to protect more. Historical urban centers have begun to be viewed as isolated and distressed areas, not as a stakeholder of the urban transport system. Issues such as the damage of the protection of the living spatial problems and the destruction of the historical environment have begun to be encountered. Troubles such as air/noise pollution, deterioration of urban image and vibration of vehicles caused damage to historical texture and brought together new planning approaches. There is a need for applications and approaches that will successfully integrate historic environments and transportation systems into the urban transport and land use fiction.

In this study, the spatial structure and transportation structure of Selçuk-Sirince, which is a strong historical environment containing intensive transportation demands, is analyzed. Principles, strategies and approaches to overcome transportation problems have been developed. The approach is made in 3 categories as analysis, problem determination and strategy production. It has been determined that Sirince is experiencing spatial damage and that transportation problems are in both vehicular and pedestrian dimensions in conclusion a solution proposal is presented.
\end{abstract}

Keywords: Historical environment, Transportation, Sirince.

1 Dr. Öğr. Üyesi, Pamukkale Üniversitesi, Şehir ve Bölge Planlama Bölümü, Denizli, Türkiye, E-mail: ggulhan@pau.edu.tr 
Tarih boyunca kentler ve ulaşım etkileşim içerisinde olmuştur. Bu etkileşimin türleri ve şiddeti, ulaşım türlerinin, araçların ve mekânların zaman içinde değişimi ile birlikte farklılaşmıştır. Ulaşım özellikleri ve yerleşim dokuları arasındaki bu ilişki tarihin sosyal, mekânsal ve ekonomik özelliklerine göre şekillenmiş ve bu bağlamda her dönemde yeni ve farklı etkileşim olanakları yaratmıştır. Sanayi devriminden sonra kentlerde yaşanan hızlı ve şiddetli genişleme, ulaşım aksları ile ilgili bağlantılarının yeni ölçekler için oluşturulması, tarihi çevrelerde yaşayan sokak dokularını yeni kent dinamiğinden ayrıştırmıştır. Yaşanan hızlı ve kontrolsüz büyümenin etkileri kentlerin ölçeğini yeniden belirlerken tarihi çevreler bu ölçek içerisinde tam olarak çözümlenememiş olup tarihi çevreye yönelik uygulamalar daha çok korumaya yönelik oluşturulmuştur. Tarihi kent merkezleri kentsel ulaşım sisteminin bir paydaşı olarak değil, izole ve ulaşım açısından sıkıntılı alanlar olarak görülmeye başlanmıştır. Yaşanan mekânsal sorunların çözümünde koruma olgusunun zarar görmesi ve tarihi çevrede tahribatlar oluşması türünde sorunlar ile karşılaşılmaya başlanmıştır. Hava/ses kirliliği, kent imgesinin bozulması ve taşıtlardan oluşan titreşimlerin tarihi dokuya zarar vermesi gibi sorunlar yeni planlama yaklaşımları arayışlarını beraberinde getirmiştir. Tarihi çevre ve ulaşım sistemlerini kentsel ulaşım kurgusuna başarı ile entegre edecek uygulama ve yaklaşımlara intiyaç duyulmaktadır.

Bu çalışmada, yoğun ulaşım talebi içeren ve güçlü bir tarihi çevre niteliği olan Selçuk-Şirince Köyü’nün mekânsal yapısı ve ulaşım kurgusu analiz edilmiştir. Ulaşım sorunlarının çözümü ile ilgili ilkeler, stratejiler ve yaklaşımlar geliştirilmiştir. Anılan yaklaşım analiz, sorunların belirlenmesi ve strateji üretimi olmak üzere 3 kategoride yapılmıştır. Şirince'nin mekânsal tahribat yaşadığı, ulaşım sorunlarının hem taşıt hem yaya boyutunda olduğu tespit edilmiş olup çözüm önerileri sunulmuştur.

Anahtar Kelimeler: Tarihi çevre, Ulaşım, Şirince.

\section{GiRiş}

Tarihi çevre, bir kente dair kültürel birikimin varlığının göstergesidir. Tarihi çevreler toplumların geçmişi ve bugünü arasında bağlantı kuran, tarihsel, mimari, arkeolojik ve anıtsal değerler ile bütünlük gösteren, yüzyıllar boyunca insanların ve canlıların yaşadığı, iz bıraktığı kentleşme türleridir (Avcıoğlu, 2009). Tarihi kentsel çevreler ve tarihi kent dokuları kentlerin kimliklerini ve kültürel geçmişlerini günümüze taşıyan mekânlardır. Bu dokular inşa edildikleri dönemin kültürünü, mimarisini, sosyal ve ekonomik durumunu, dini inancını yansıtan yapılar olduğu gibi bir bölgenin yöresel niteliklerini, doğal ve arkeolojik özelliklerini de yansıtan yapılardır (Avcıoğlu, 2009). Fakat tarihi çevreler artık tehlike altındadır.

Günümüzde artan iş olanakları, hızlı nüfus artışı, özellikle 1950'li yıllardan sonra köyden kente göç vb. nedenlerle kentleşme hızla artmakta olup, düzensiz ve karmaşık yapılaşmaya neden olmakta ve bunun sonucunda fiziksel çevre olumsuz yönde etkilenmektedir (Güreşçi, 2011). Fiziksel çevrenin olumsuz etkilenmesi tarihi kent dokularını, çevreyi ve ona bağı mekânları da olumsuz yönde etkilemektedir. Korumaya dair kuralların, kanunların ya da uygulamaların yetersiz oluşu nedeniyle tarihi çevreler özellikle güçlü ekonomiye ve gelişmiş koruma bilincine sahip olmayan ülkelerde bozulmaya hatta gittikçe yok olmaya başlamıştır (Yaşlıca ve diğ., 2017). Tarihi çevrelerde tarihi dokuyu ezen ve ikinci plana atan yeni yapılaşmalar, yeni ulaşım aksları ve faaliyetler görülmektedir. Tarihi bölgelerde oluşturulan yeni yapılar, karmaşık ve dışlayıcı mekânlar, eski dokuyla ilişkisi düşünülmeden tasarlanması nedeniyle tarihi dokunun bütünlüğünü bozmakta ve kültürel miras olarak kabul edilen dokunun sürdürülebilirliğini tehlikeye atmaktadır. Anılan sorunlar sadece hızı kentleşme ve nüfus artışı nedeniyle oluşmamaktadır. Zaman içinde toplumların kültürlerinde, sosyo-ekonomik yaşamlarında yaşanan değişmeler, yeni kullanım 
biçimleri, yeni tüketim biçimleri, yeni toplumsal alışkanlıklar ve benzer değişimler tarihi dokular ile sokaklarda mekânsal ve sosyolojik olarak hissedilmektedir.

Bir mekân olarak sokak, toplumların işlevsel ve kültürel etkileşimi açısından yoğun faaliyet gösterdiği alanlardır. Bu bağlamda düşünüldüğünde sokaklar günümüzdeki tarihsel mekân kullanımları ile yoğun etkileşim alanlarına sahiptir. Çünkü tarihi kentsel dokulardaki sokaklar, yayaya ya da atlıya göre oluşturulmuştur. Bu sebeple ulaşım ağı organiktir. Tarihi çevrelerde yer yer genişleyen ve daralan sokaklar aynı zamanda çıkmaz sokaklar da tarihi sokakların önemli özelliklerindendir (Yaşlıca ve diğ, 2017). Dolayısıyla, sokak temel ulaşım elemanı olarak tarihi çevrelerin ulaşım dokusunu belirleyici konumdadır. Bazı durumlarda birkaç sokağın oluşturduğu kavşak önceden tarif edilmemiş bir genişliğe erişebilmektedir. Bu genişliklerin bir dükkânı, bir çeşmeyi veya bir mescidi tanımladıkları, tamamladıkları veya onlara erişim sağladıkları görülmektedir. Bu yol ayrımlarından daha önemli bir yol ayrımı ise bir cami veya mektebe bağlanabilmesidir. Bu alanlar eski zamanlarda çoğunlukla toplanma alanı olarak değerlendirilmiştir. Bu bölgelerde ulaşımın erişilebilirliği sağlamak ve mekânsal etkileşimi tamamlamak için arazi kullanım türlerine göre şekillenmesi ve yönlenmesi görülmektedir. Böylece ulaşım ve arazi kullanımı arasındaki organik etkileşim sokak ölçeğinde net olarak anlaşılabilmektedir. Tarihi dokularımızda görülen bu sokak düzenlenmeleri, yapıldıkları dönemin sosyal ve ekonomik gereksinimlerini karşılamak amacıyla yapılmış olup günümüz gereksinimlerini karşılamakta yetersiz kalmaktadır. Giderek değişen, dönüşen yaşam biçimi ve kalitesi farklı istekler doğurmuş ve farklı yaşam mekânlarının oluşmasına neden olmuştur. Bugün, kentlerimizde yaya erişilebilirliği kapsamında oluşmuş ölçeğini koruyabilmiş ve doğal organik formlarını kaybetmemiş tarihi doku oldukça azdır. Özellikle büyük kentlerde korunmuş ve değişime uğramamış eski dokuların varlığını sürdürdüğünden söz etmek pek olanaklı değildir (Yaşlıca ve diğ, 2017). Bir yandan büyük yangınlar, etkin doğal afetler eski dokuları yok etmiş ya da onlara zarar vermiş, diğer yandan bu mahallelerin yeni sakinlerinin batı örneklerini bilinçsizce uygulamaları, birbirini uyum içinde tamamlama endişesine sahip eski yapılaşma biçimlerini bozma yolunda gösterdikleri olumsuz büyük çabalar eski devirlerden hiçbir şey bırakmamıştır (Aru, 1998).

Anılan sorunlar, arazi kullanımı ve ulaşım arasındaki etkileşimi doğrudan etkilemekte ve tarihi çevrelerde mekânsal etkileşimin şiddetini ve niteliğini düşürmektedir. Tarihi kent merkezleri geleneksel yaşam ve turizm çekiciliğinin bir arada olduğu yerleşmeler olarak mekânsal, ekonomik ve yönetim temelli sorunlar ile karşı karşıya kalmaktadır. Tarihi çevrelerdeki mekânsal temelli sorunlar incelendiğinde öncelikle mevcut yol sistemlerinin güncel ihtiyaçları yani günümüze dair mekânsal etkileşim taleplerini karşılamakta yetersiz kaldığı görülmektedir. İnsan ölçeğinde kurulan kentlerde yer alan çıkmaz ve dar sokaklar, motorlu araç trafiğinin kullanabileceği standartlara sahip değildir. Bununla birlikte kent merkezine giriş yapan araçlar için otopark sorunu da önemli bir sorun olmaktadır. Açılan yeni yollar araç sirkülasyonunda bir rahatlama yaratsa da bu sorunlar tamamen aşılamamıştır (Uzun, 2010). Özel taşıt sorunlarına ek olarak toplu taşıma erişimi, yaya ve bisiklet erişimi, ulaşımda entegre sistemlerin kullanımı, denetleme, yönetim ve bilgilendirmeye dair sorunlar ile de karşılaşılmaktadır.

Cazibe niteliği taşıyan kent merkezleri ekonomik aktivitelerin yoğunlaştığı alanlar olması sebebiyle sürekli dönüşüm içerisinde yer almaktadır. Tarih boyunca metropoliten merkezlerde yeni işlevler ve değişimler görülmüş, buna bağlı olarak hem yerleşime yeni açılan alanlar hem de eski şehir merkezlerinde bulunan konut alanları farklılaşmalara bağlı olarak değer kazanmıştır. Bu farklılaşmaya bağlı olarak yeni yerleşim alanları için ulaşım, daima sorun olmuştur ve yüksek maliyetli müdahaleler gerektirmiştir. Bu maliyeti yerel yönetimler karşılayamamaktadır. Tarihi kent merkezleri bu nedenlerle ulaşım açısından birer darboğaz alanı olmaktadırlar. Bu da ulaşım açısından ekonomik temelli bir sorun oluşturmaktadır (Yaşlıca ve diğ, 2017).

Ulaşım sistemi, seçimi ve tercihlerinde karayolu ulaşım sistemine öncelik verilmiş, paralelinde özel araç sayısı artış göstermiş ve özel otomobil kullanma eğilimi de artmıştır. Bu eğilim eski şehir merkezlerinde 
var olan sosyal ve kültürel olanakları ve ekonominin biçimlendirdiği ilişkileri ve ulaşım sistemini tamamen değiştirmiştir. Bu problemlerin çözümü noktasında önemli rol üstlenmesi gereken yerel yönetimlerin bu konuya yaklaşımı sorunun yol ile araç miktarı arasındaki farlııktan kaynakladığını varsayan trafikçi bir yaklaşımdır. Bu bağlamda çözüm önerisi olarak yeni arter açma yolu seçilmiştir. Bu yaklaşımın sonucunda pek çok tarihi çevrede trafik kent merkezleri içerisine alınmıştır (Uzun, 2010).

Bu çalışmada, tarihi çevrede ulaşım sorunlarının analizi, arazi kullanımı ile etkileşimi göz önünde bulundurularak yapılmıştır. Sorunların nedenleri ve giderilebilmesi ile ilgili araştırmalar yapılmış olup tarihi çevrelere yapılacak müdahaleler ile ilgili ilkeler, stratejiler ve yaklaşımlar geliştirilmiştir. Anılan yaklaşımlar yoğun ulaşım talebi içeren ve güçlü bir tarihi çevre niteliği taşıyan Selçuk-Şirince Köyü üzerinden değerlendirilmiştir.

\section{YÖNTEM}

Şirince'nin ulaşım stratejilerinin belirlenmesinde 3 etaplı bir yöntem geliştirilmiştir. Birinci etap, Şirince'nin mevcut ekonomik, sosyal ve mekânsal arka planın ortaya konulmasıdır. Böylece Şirince'nin ulaşım stratejileri bağlamında geleceği için alınacak kararların etkilerinin çok yönlü değerlendirilmesi mümkün olacaktır. İkinci etapta, her ölçekteki planlama engelleri ile ulaşıma dair doğrudan veya dolaylı sorunlar tespit edilecektir. Üçüncü etapta, ise Şirince'nin sürdürülebilir yönetimi ve korunmasına yönelik parametreleri tanımlayan ulaşım stratejileri oluşturulmuştur. Bu kapsamda, ulaşım stratejileri, Şirince'nin mekânsal ve işlevsel altyapısının korunması-geliştirilmesi ve etkin kullanımına yönelik planlama sürecinin tanımlanmasına çözümler sunan yol haritası olarak görülmelidir.

\section{MEKÂNSAL ve IŞLEVSEL ARKA PLAN}

Şirince yerleşkesinin var olan tarihsel geçmişine ilişkin bilgiler eşliğinde kültürel ve doğal miras kaynaklarının biçimlendirdiği mekânsal karakter ve işlevsel kimlik değerlerinin tanımlanması, ulaşıma dair sorunların belirlenmesi yerleşimin korunması ve geliştirilmesi açısından önemlidir. Bu anlayış doğrultusunda, Şirince yerleşkesinin mevcut-fiili durumu ayrıntıda analiz edilmiştir.

\subsection{Konumsal nitelik ve ulaşım ilişkileri}

Şirince yerleşimi, Ege Bölgesi'nin kuzeybatısında bulunan, İzmir ili'’ne bağlı Selçuk İlçesi'nin idari-coğrafi sınırları içinde, günümüzde özellikle turizm rotaları açısından değerlenen bir tarihi çevredir. Yakın çevresinde Efes, Artemis Tapınağı, Meryemana, St. Jean, Yedi Uyuyanlar gibi tarihi inanç merkezleri, Dilek Yarımadası-Büyük Menderes Deltası Milli Parkı gibi kültür-doğa turizmi merkezleri ve alternatif turizm faaliyetleri mevcuttur. Birinci derece turizm odaklarl; turizmden en fazla kazancın beklendiği ve her noktasının gezilip görülmeye değer olduğu en önemli odak türüdür. İkinci derece turizm odakları; Şirince'de yayla turizmi, şarapçılık, ev pansiyonculuğu, tarım turizmi; Göller Bölgesi'nde ise kuş gözlemciliği ve safari gibi etkinliklerden oluşmaktadır. Anılan turizm potansiyellerinin konumları Şekil 1 'de gösterilmiştir. 


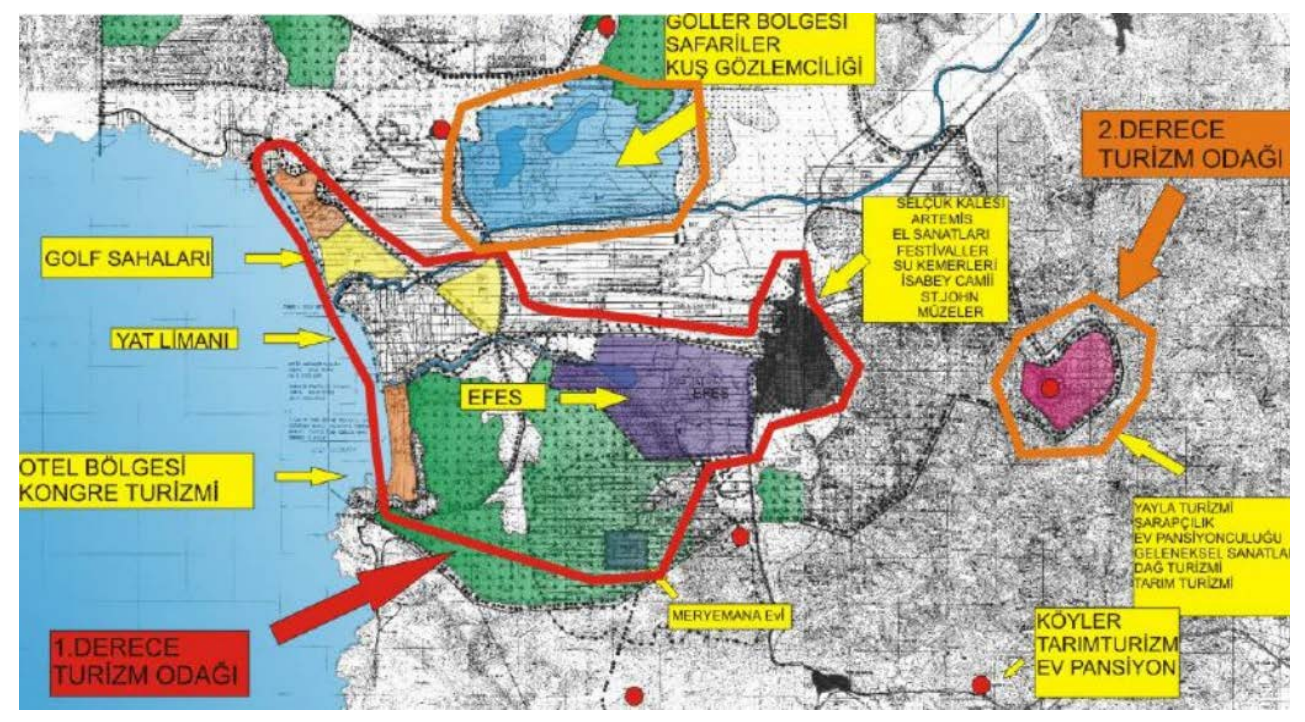

Şekil 1. Bölgedeki turizm odakları ve potansiyellerinin konumları (Gulhan, 2007).

Bu kapsamda günübirlik ziyaret edilen, geçiş noktası işlevinde, turizm amaçlı yoğun mekânsal etkileşime sahip tarihsel bir alan niteliğindedir. Ulaşım ilişkileri doğrultusunda incelenecek olursa Şirince'nin gerek ülke gerek bölge ile tek ulaşım bağlantısı Selçuk üzerindendir. Şekil 2'de Şirince'nin bölgesel konumu ve bağlantıları gösterilmiştir. Turuncu renk demiryolunu, kırmızı renk ana ulaşım aksını ve sarı renk ikincil derece yolları tanımlamakdır.

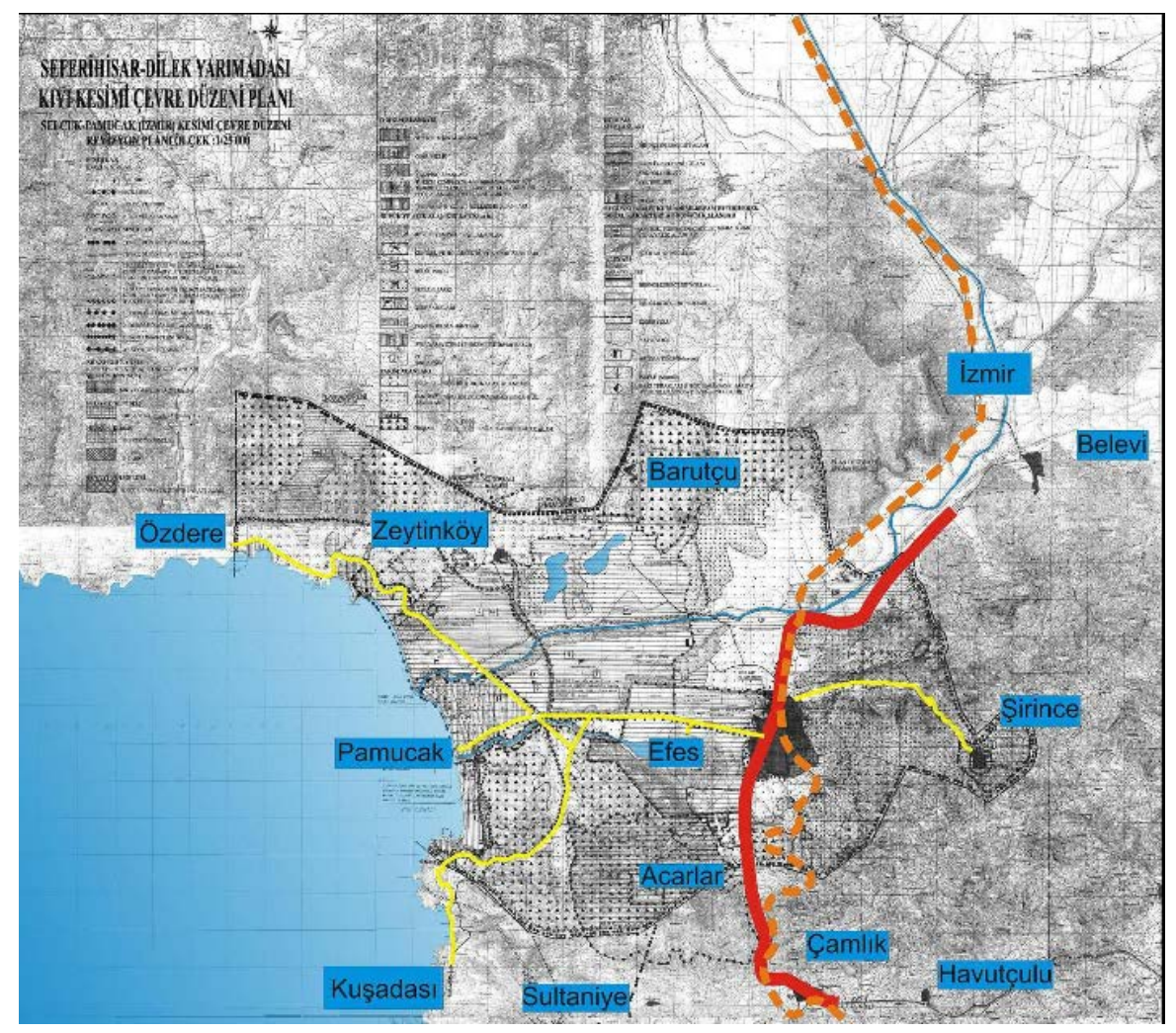

Şekil 2. Şirince'nin bölgesel konumu ve bağlantıları (Gulhan, 2007).

Bu noktadan itibaren İzmir ili'nin tüm gelişmiş karayolu, demiryolu, denizyolu ve havayolu ulaşım olanaklarını kullanma olanağına sahiptir. İzmir-Aydın otoyolunun, Belevi Köyü çıkışı Selçuk üzerinden Şirince'ye ulaşım olanağı vermektedir. İzmir İli’ndeki havalimanlarından biri olan Pamucak Havalimanı 
Şirince'ye 10 kilometre uzaklıkta olup, Uluslararası Adnan Menderes Havalimanı ise 70 kilometre mesafede bulunmaktadır. $20 \mathrm{~km}$ mesafede Şirince'nin turizm potansiyeli açısından önemli olan Aydın'a bağıı Kuşadası Uluslararası Liman ve Yat Limanı bulunmaktadır.

\subsection{Mekânsal karakteristik ve işlevsel kimlik/statü}

Selçuk'tan gelen yolların Şirince'ye ulaştığı noktada küçük bir tepe üzerine konumlandırılmış olan ve köye girişte ilk algılanan yapı olan St. Dimitrios Kilisesi bulunmaktadır. Bu kilise genellikle Aşağı Kilise olarak anılmaktadır. Aşağı Kilise'nin karşısında bulunan ilkokulun geniş bir bahçesi bulunmaktadır. Şirince'nin yerleşim dokusu, arazinin topoğrafik yapısına bağlı olarak kademelidir. Yerleşim dokusu ve arazinin topoğrafik yapısını gösteren kent planları, kent fotoğrafları, hava fotoğrafları, hâlihazır haritalar Şekil 3 ve Şekil 8 arasında farklı haritalarda gösterilmiştir. íki yamaca yerleşmiş olan yapılar eş yükseklikli sıralar halinde dizilmiş ve birbirinin görünümüne engel olmamıştır. Vadinin batı yamacındaki i̇stiklal Mahallesi'ndeki yapıların cepheleri doğuya bakarken sokaklar eğime paralel olarak kuzey-güney doğrultusundadır. Buna karşılık güney yamaçtaki i̇stihlas Mahallesi'ndeki yapılarının cepheleri kuzeye bakmakta ve sokaklar doğu-batı doğrultusunda uzanmaktadır. Her iki yamaçta da bu yolları kesen, eğime dik yokuşlar, merdiven basamaklı sokaklar ya da az katı sokaklar köy meydanında buluşmaktadır. Köy meydanı, yalnızca sokakların buluştuğu değil, aynı zamanda tüm köyün bir araya geldiği, düğünlerin yapıldığı, turistlerin dinlendiği bir buluşma noktası niteliğindedir. Şirince köyü yerleşik alanı 1984 yılında kentsel sit alanı olarak ilan edilmiştir (Kılıçarslan ve diğ., 2012). Alanda doğrudan sokağa açılan konut örnekleri olmasına karşın avlu ve bahçe kullanımı yaygındır. Köyün batı yamacında yer alan yerleşim dokusunda, doğrudan sokağa açılan avlusuz/bahçesiz konut sayısı çok daha fazladır. Bu konutların ana cepheleri sokağa bakmakta ve giriş buradan sağlanmaktadır. Şirince'nin temel işlevsel kimliği günümüzde tarih ve doğa turizmi bağlamında ticari faaliyetlerle bütünleşen bir yapıdadır (Köşklük Kaya N., 2012) . Kentin kültürel ve doğal yerleri, yerli ve yabancı pek çok turist tarafından 365 gün boyunca ziyaret edilmektedir. Ticaret koridorlarının kent meydanından diklemesine barınma alanlarına doğru uzandığı organik bir etkileşim bulunmaktadır. Şekil 3'te konut alanları ve ticaret alanlarının etkileşimi ile ilgili görsel verilmiştir. Hediyelik eşya ve turiste yönelik günübirlik ticaret yanında konaklama sektörleri ön plana çıkmaktadır.

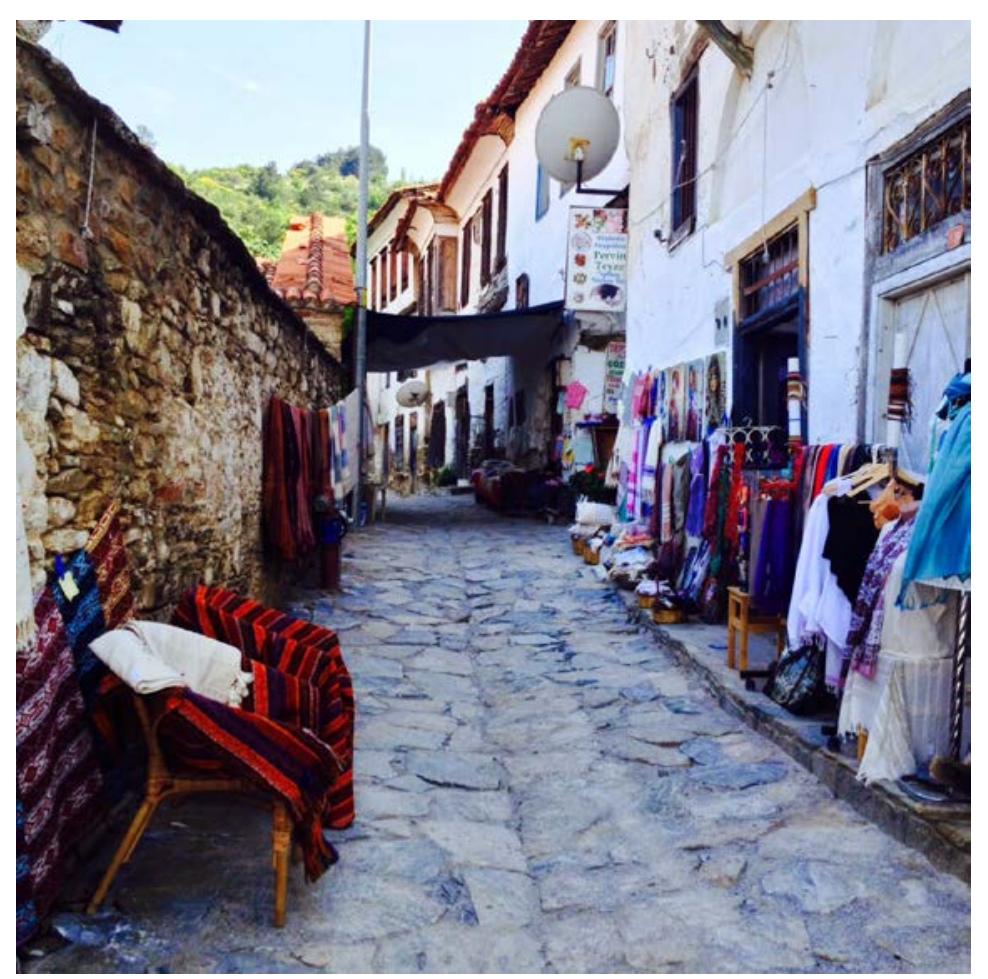

Şekil 3. Ticaret ve konut alanları etkileşimi. (Pamukkale Üniversitesi, 2016) 


\subsection{Ulaşım altyapısı ve analizi}

Şirince'nin çevresindeki ilçelere erişim anlamında iki bağlantısı vardır. Bu yollar Eski Yol ve Yeni Yol olarak adlandırılmaktadır. Selçuk i̇lçe Merkezi'nden doğu yönünde ayrılan asfalt kaplamalı, 8 km uzunluğundaki köy yolu, Şirince'nin içinde yer aldığı coğrafya ile en önemli bağlantısını oluşturmaktadır. Anılan yolda zaman zaman erozyon nedeniyle bozulmalar görülse de yılın tamamında açık tutulmaktadır. Şirince'ye girişten itibaren yol kademelenmesi küçülerek, kent içi yol başlamaktadır. Kent içi ulaşımın algılandığı bu nokta küçük bir kavşak biçimindedir. Sokaklarda organik, kendiliğinden oluşmuş, ticaret ve barınma alanları ile küçük ölçekli ilişkilere hizmet edebilen dokunun hâkim olduğu görülmektedir. Ulaşım ağının temel şekillenme kaynağı topografyadır. Yolların genişliği 3-4 metre olup bazı yerlerde 2 metreye kadar daralıp bazı yerlerde de 6 metreye kadar genişlemektedir. Şirince Köyü’nün yol kademelenmesi analizi yapılmış olup şekil 4'de verilmiştir.

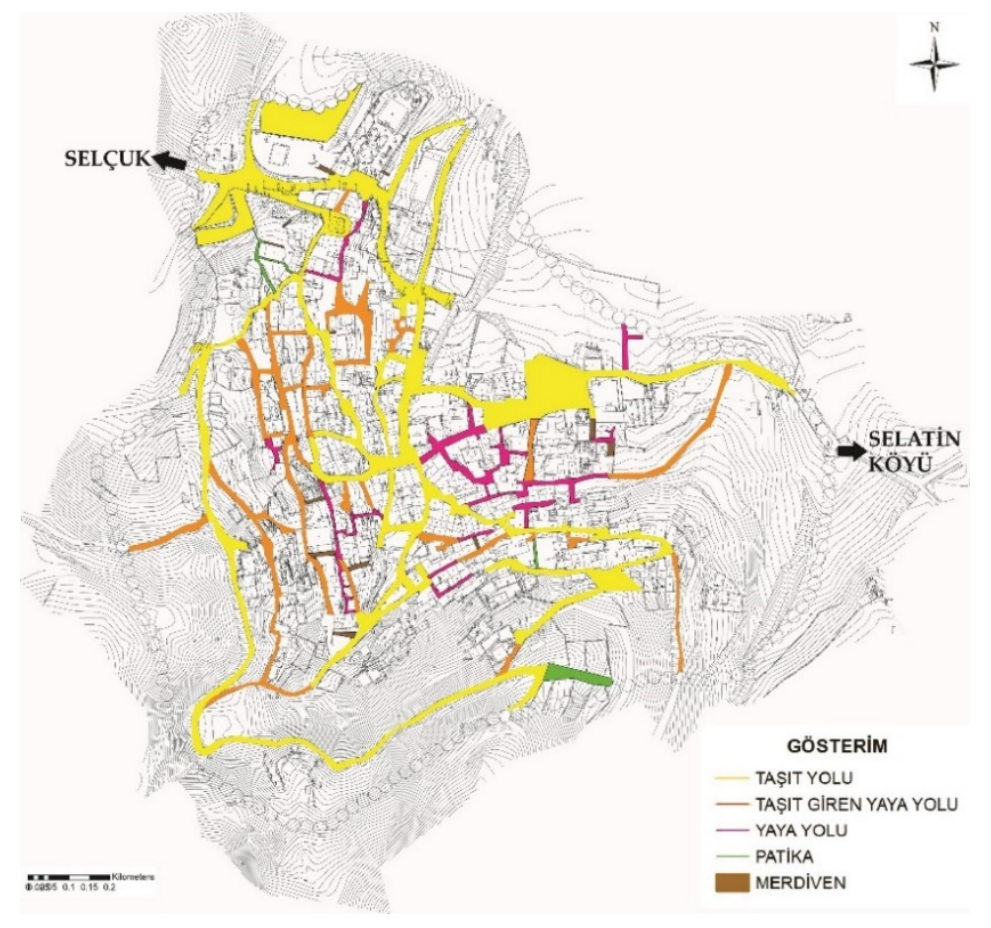

Şekil 4. Şirince yol kademelenmesi analizi (Pamukkale Üniversitesi, 2016).

Şekil 4'deki analizde yollar 5 aşamada incelenmiştir. Köyün ulaşım ağı taşıt yolu, taşıt giren yaya yolu, yaya yolu, patika ve merdivenler olarak kademelendirilmiştir. Günümüz kademelenme anlayışına uygun bir yol sistemi yoktur. Yüksek kademe yollar arada başka kademe yol bulunmadan en küçüğe kadar bağlanabilmektedir. Yolların genişliği 3-4 metre olup bazı yerlerde 2 metreye kadar daralıp bazı yerlerde 6 metreye kadar genişlemektedir. Hemen her sokakta aydınlatma elemanı bulunmaktadır.

Köyün en önemli potansiyellerinden birisi yoğun tarihi ve kültürel özellik gösteren sokaklarıdır. Şirince'nin tarihi sokak dokusunu Arnavut kaldırımlar oluşturmaktadır. Arnavut kaldırımlı dar sokaklar kayrak tabir edilen taşlar kullanılarak yapılmıştır. Kayrak taşları avlu zemin döşemelerinde de kullanılmıştır. Yollar dar ve engebelidir ve araç yolu için uygun altyapı bulunmamaktadır. Şekil 5'te Şirince'deki yol üst yapısın örnekleri verilmiştir. Şirince'nin yol üst yapı tiplerinin analizi Şekil 6'da verilmiştir. 


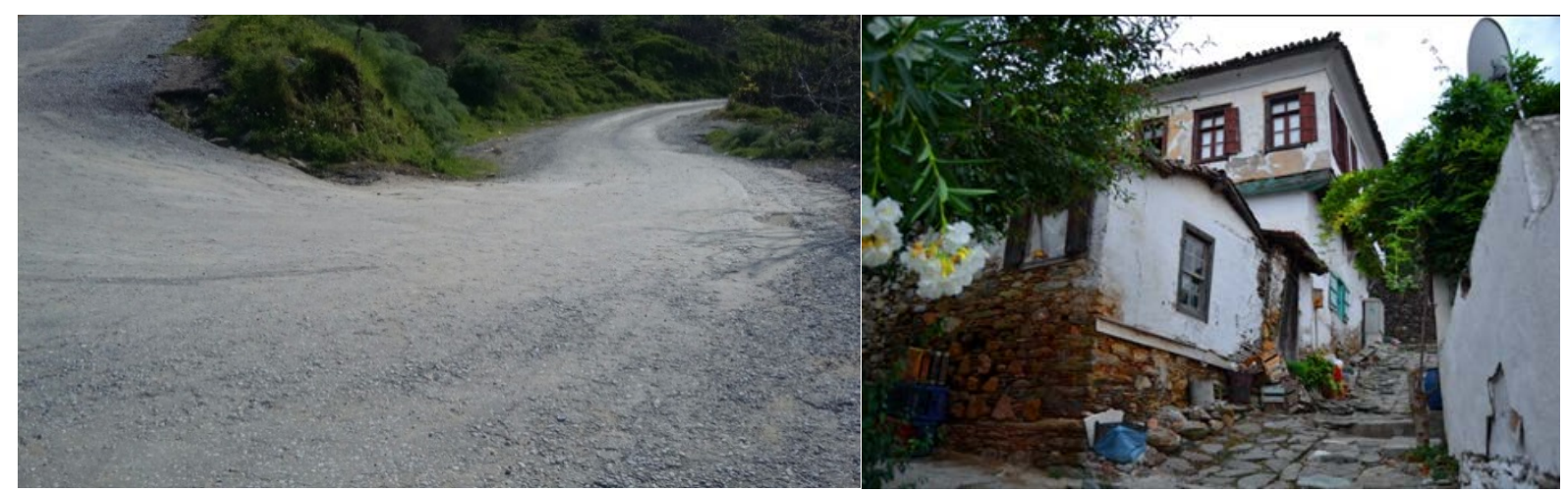

Şekil 5. Yol kesitleri. (Pamukkale Üniversitesi, 2016)
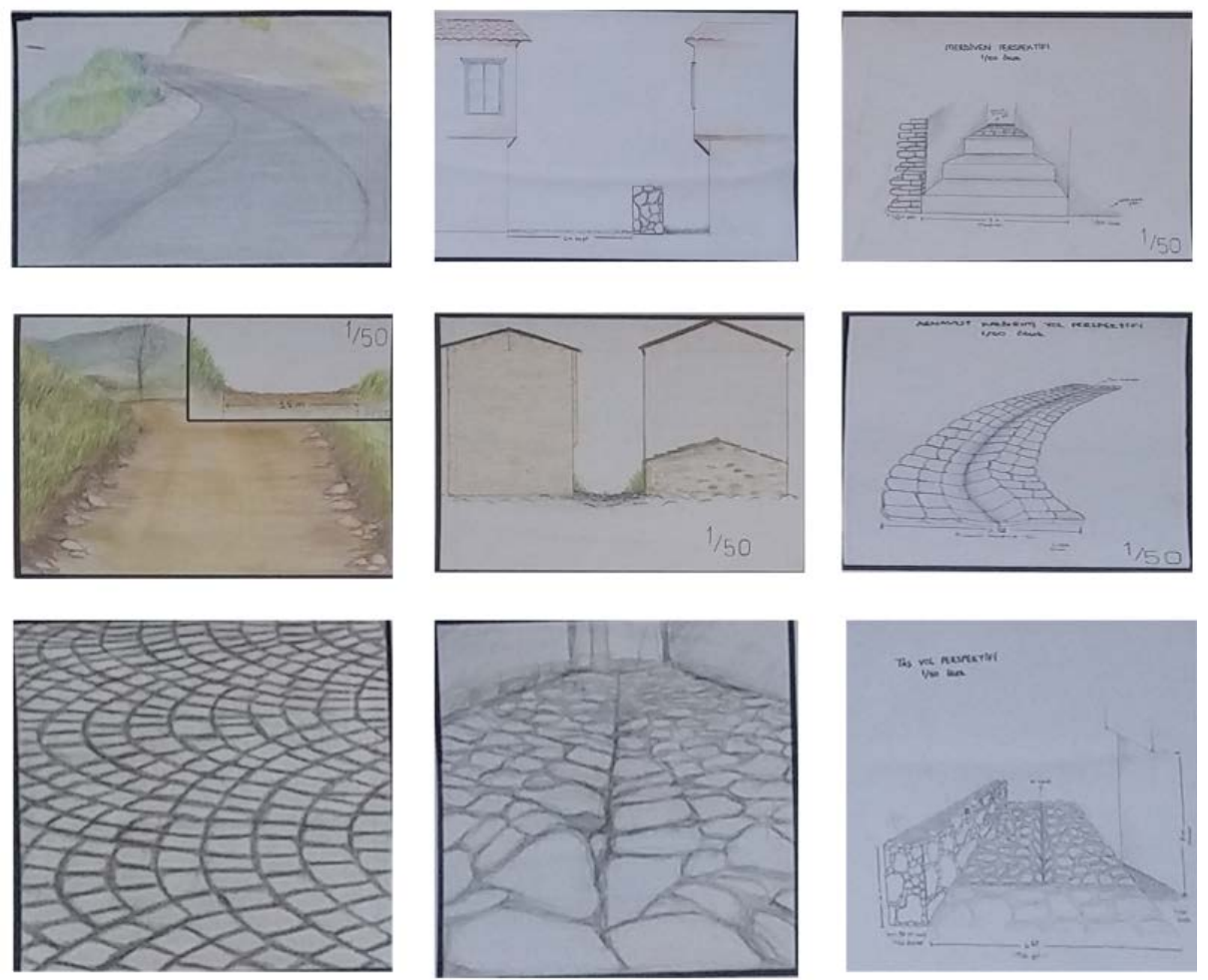

Şekil 6. Yol kesitleri analizi (Pamukkale Üniversitesi, 2016)

Şekil 6 incelendiğinde, yol kaplama çeşitlerinin; asfalt yol, taş kaplamalı yol, Arnavut kaldırımı ve toprak yol olmak üzere 4 gruba ayrıldığı görülmektedir. Anılan asfalt yol Selçuk'tan Şirince'ye uzanan, dar ve oldukça virajlı olan ana erişim güzergâhıdır. Bu yolda zaman zaman rastlanılan bozulmalar ve çökmeler trafik güvenliği açısından önem arz etmektedir. Taşıt erişimli yollarda genel olarak asfalt ve taş yol kaplama çeşidinin kullanıldığı görülmektedir. Taş yollarda yaşanan en önemli sorunlardan birisi ise yük araçları ile tarlalara giden iş araçlarının yollara verdiği zararlardır. Yaya yollarının genel olarak toprak yol olarak teşkil edildiği görülmüştür. Yol kaplama çeşitlerinin sürekli olarak zarar görmesi devamlı bir tadilat talebi yaratmakta olup özellikle asfalt yollarda bu durum daha fazla gözlemlenmektedir.

Şirince'ye ziyaret amaçlı gelen turistlerin büyük çoğunluğu Şirince'nin geleneksel dokusunu görmek, sokaklarında yürümek ve geleneksel lezzetlerini tatmak için gelmektedir. Şirince'de Mart 15 ve Kasım 15 arasında gelen turistlerin çoğunluğu yabancıdır. Bu tarihler arasında tahmini bir oran söylenecek olursa yaklaşık \% 65'i yabancı ve \% 35'i yerli turist oluşturmaktadır. Diğer tarihler arasında ise yaklaşık \% 60'ı 
yerli ve \% 40'ı yabancı turisttir. Yabancı turist ve yerli turist sayıları birbirlerine yakındır (Ongun, U. ve Gövdere B., 2015). Yerli turistler genellikle hafta sonu gelirken yabancı turistler turlarla gelmektedir (Semenderoğlu ve Oban, 2007). Yerli turistlerin bir kısmı turlarla bir kısmı ise özel araçlarıyla gelmektedir. Şirince önemli destinasyonlara komşu bir köy olduğu için günübirlik turların düzenlendiği turistik bir çekim noktası haline gelmiştir. Turistlerin en çok zaman geçirdikleri alan köy çarşısıdır. Çarşıyı, yol boyunca evlerinin önünde bulunan tezgâhlarda yaptıkları el sanatlarını satan kadınların kurduğu ticari alanlar oluşturmaktadır. Bu bölge yaya akımı ile ticaret etkileşiminin en yüksek olduğu koridor ve akslarıdır. Şekil 7'de yaya erişim ve ticaret aksı fotoğrafları gösterilmektedir.

Şirince'nin girişinde otopark alanı mevcuttur. Bu alan ortalama 4000 m2 olup ortalama 200 araç kapasitesindedir. Özellikle bahar ve yaz aylarında bu alan tamamen dolmakta ve gelen araçlar Şirince Selçuk yolu boyunca yol kenarı parklanması yapmaktadır. Böylelikle Şirince girişinde park halindeki araç sayısının bahar ve yaz aylarında 1000 aracı geçtiği tespit edilmiştir. Şirince'ye araç girişi bu dönemlerde güvenlik güçleri tarafından engellenmektedir.
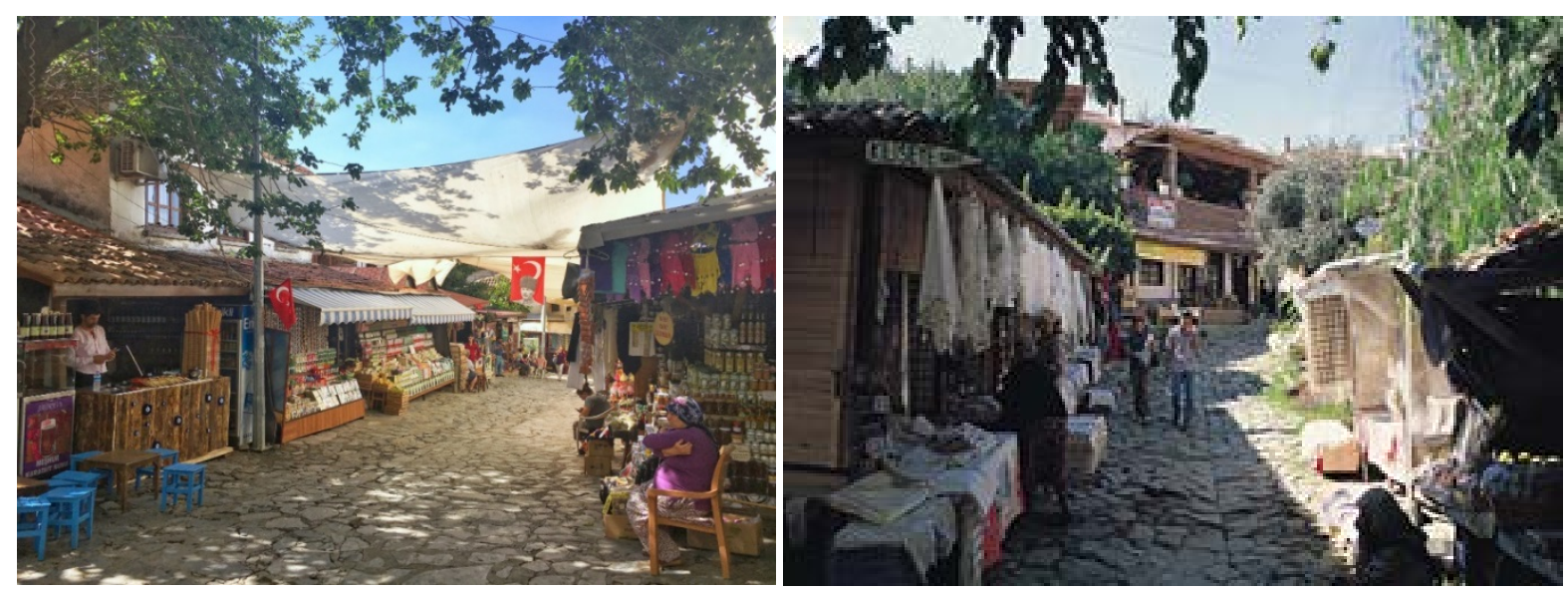

Şekil 7. Köy Çarşısı. (Pamukkale Üniversitesi, 2016)

Şirince'ye toplu taşıma ulaşımı, Selçuk İlçe Merkezi'nden 20 dakika aralıklarla karşlıklı sefer yapan minibüsler ile sağlanmaktadır. Yazları fazla yoğunluktan dolayı 7 adet minibüs 20 dakikada bir sefer yapmakta ancak kışın anılan sefer sıklığı değişmekte ve saat başı sefer yapılmaktadır.

Şirince'de tarımsal ürünlerin taşınması nedeniyle yük hareketliliği mevcuttur. Şirince'nin tarımsal üretiminin çok büyük bir bölümü tüccarlara satılmaktadır. Alanda yapılan tespitlere göre tarımsal ürünlerin \%75'inin tüccara ve fabrikalara, kalanının da doğrudan tüketiciye satıldığı belirlenmiştir. Oluşan yük hareketi Şirince içi trafiği veya Şirince'ye oluşan erişim kalitesini etkileyecek boyutta değildir. Yük ve lojistik hareketliliğin trafiğin yoğun olmadığı saatlerde yapıldığı bölge esnafı ile yapılan görüşmeler sonucunda tespit edilmiştir.

\subsection{Sosyo-ekonomik özellikler}

Şirince'de temel ekonomik yapıyı belirleyen önemli iki sektör tarımsal üretim ve turizme yönelik ticari aktivitelerdir. Şirince'nin yüzyıllardır geçim kaynağı tarımsal üretimdir. 1980'li yılların ortalarından itibaren turizm ikinci bir sektör olarak ortaya çıksa da tarım sektörü bir adım önde olmuştur. Zamanla turizme yönelik ticari aktivitelerde çalışan iş gücü sayısı artmış olup bu durumda kadınların evlerinin önüne açtıkları sergiler önemli rol oynamıştır. Şirince'ye yönelik dış turizm potansiyelini, Selçuk'un turizm potansiyelinden ayrı düşünmek doğru değildir. Yalnızca Şirince hedefli tur olmayıp Antik Efes Kenti, 
Artemis Tapınağı, Meryemana Evi, St. Jean Kilisesi gibi dünya uygarlık tarihinin en önemli örneklerini barındıran Selçuk Yöresini hedefleyen turların bir bölümüne "eski bir Rum Köyü" ya da "otantik bir Türk Köyü" adı altında Şirince de eklenmektedir. Şirince, tarihsel, fiziksel, sosyal, ekonomik özellikleri nedeniyle dışa açık bir yerleşme birimidir. Bu durumda Hristiyan bir Rum köyü olmasının etkisi de oldukça fazladır. Hristiyan kültürünün etkisiyle dışa dönük bir yapıya sahiptir. Şirince'nin gerek demografik ve gerekse sosyal özellikleri göz önüne alındığında, rahatlıkla kendine özgü bir yapısı olduğu söylenebilir. Demografik yapı incelendiğinde, Şirince'nin yeniden yerleşime açıldığı 1924 yılından bu yana, ülke nüfusu yaklaşık 5 kat artış gösterirken, Şirince nüfusu üç kat azalmıştır. 2015 yılına ait en güncel Tüik verilerine göre Şirince nüfusunun 492 kişi olduğu belirtilmektedir. Genel olarak Türkiye'de yaşanan kırdan kente göç olayının yoğunlaşması, özel olarak da Şirince'de yükselen ekonomik düzeye uygun kentsel servislerin sunulmaması sonucu, genç nüfus hızla Şirince'den uzaklaşmaya başlamıştır. Tablo 1'de Şirince Köyü’nün yıllara göre nüfus değişimi verilmiştir.

Tablo 3.1. Şirince Köyü’nün yıllara göre nüfus değişimi (Beker, 2002)

\begin{tabular}{|l|l|l|l|}
\hline SAYIM YILLARI & NÜFUS & SAYIM YILLARI & NÜFUS \\
\hline 1927 & 1740 & 2009 & 538 \\
\hline 1935 & 1288 & 2010 & 534 \\
\hline 1950 & 1019 & 2011 & 536 \\
\hline 1960 & 876 & 2012 & 530 \\
\hline 1970 & 774 & 2013 & 545 \\
\hline 1980 & 839 & 2014 & 505 \\
\hline 1990 & 787 & 2015 & 492 \\
\hline 2000 & 619 & Azalma Oranı & $\mathbf{7 1 \%}$ \\
\hline
\end{tabular}

Yıllarca kendi haline bırakılan yok edilen ve hatta yok edilme sürecini hızlandırıcı politikalar izlenen Şirince'nin geleneksel yapıları, 1978 yıından başlayarak yasal koruma altına alınmıştır. Şirince'deki idari ve yönetim tesisi Şirince Köyü Muhtarlığı olarak nitelendirilebilir. Eğitim kurumları incelendiğinde ise Şirince'de eğitim hizmetleri köyün tek ilkokulunda verilmektedir. Köyde sağlık hizmetleri Şirince Sağlık Ocağı tarafından verilmektedir. Dini tesisler incelendiğinde ise Şirince'de bir cami ve iki kilise bulunmaktadır.

\section{ULAŞIM SORUNLARI}

\subsection{Yol üst yapısına ilişkin sorunlar}

Şirince'nin yollarının bakımsız ve bozuk olması (tümsekler ve çukurlar içermesi...), zemin kaplamalarının hareketi kısıtlaması ve yürümeyi zorlaştırması yol üst yapısında yaşanan sorunların başında gelmektedir. Köy yolunda, kış mevsiminde don olaylarının yaşanması, Şirince'nin yol bakım çalışmalarının zamanında yapılmaması diğer önem arz eden sorunlardandır. Tarihi sokaklara araç girmesi yol üst yapısına ve Şirince'nin organik sokak dokusu algısına zarar vermektedir.

\subsection{Otopark sorunu}

Şirince'nin merkezinde bulunan otopark genel olarak yeterliyken, yaz mevsiminde Şirince'ye yapılan ziyaretler nedeniyle yetersiz kalmaktadır. (Semenderoğlu ve Oban, 2007) Köy yolunun kapasitenin az olması nedeni ile yol kenarı parklanması oluşmaktadır. Şirince'ye ulaşan dar ve virajı ana erişim güzergâhında yol dışı parklar yapılması yürüme mesafesinin maksimum $300 \mathrm{~m}$ olmasına ters düşsmekte ve 
trafik güvenliğini tehlikeye atmaktadır. Taşıt sahipliliğinin hızla artması ziyaretlerin özel araçlarla yapılmasını etkin kılmakta ve Şirince gibi otopark sorunu olan yerleşmelerde bu sorunu oldukça önemli ölçüde tetiklemektedir. Bu sorunun çözümü için yaz mevsimi nüfus artışıla orantılı olarak Şirince köyü otopark kapasitelerinin incelenmesi ve kapasitede beklenen değişimlerin yapılması sorunun çözümü açısından derinlik sağlayacaktır. Şekil 8' de yol kenarı otopark yapılan alanlar gösterilmiştir. Sürücüler kent içerisindeki yaya yolu özelliğindeki yollara girerek evlerinin önüne araçlarını park etmektedirler. Zaten dar olan yollar araçlar tarafından işgal edilmekte ve yaya akışını engellemektedir.

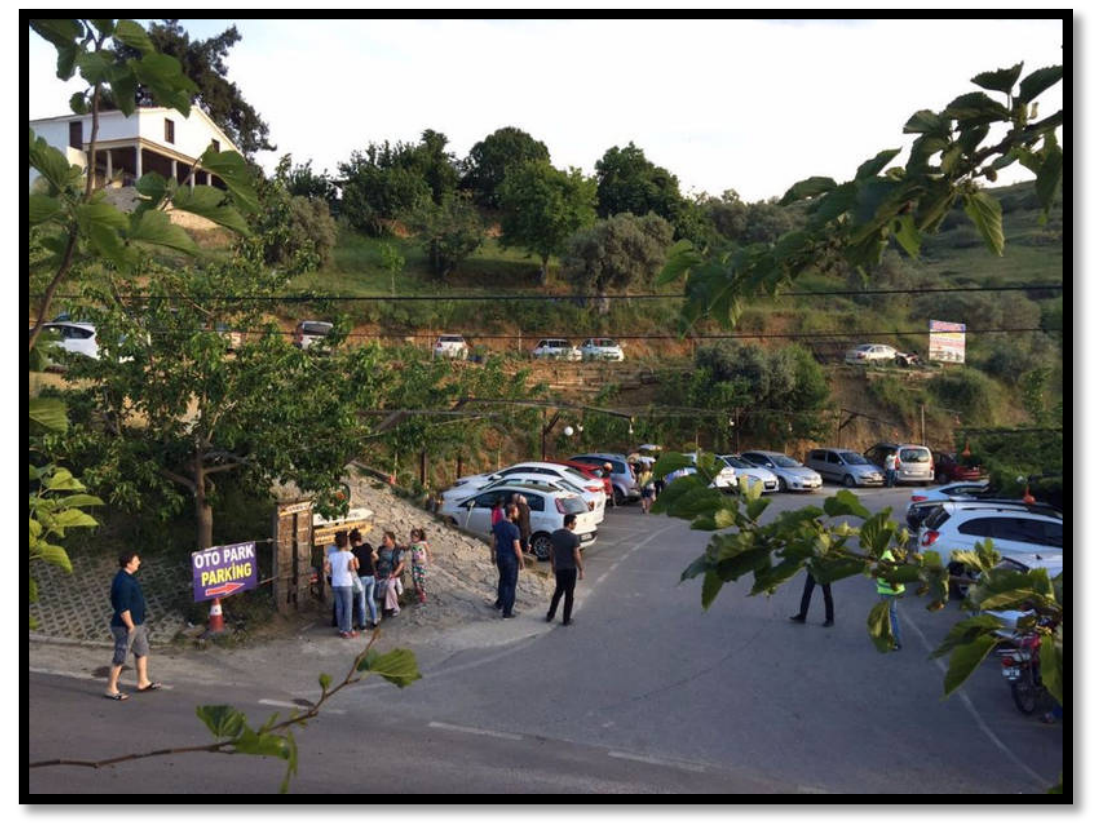

Şekil 8. Yol kenarı otoparklanma örneği. (Pamukkale Üniversitesi, 2016)

\subsection{Toplu taşıma}

Alanda toplu taşıma esnafı ile yapılan görüşmeler sonucunda, genel olarak özel araç sahipliliği artışının toplu taşıma talebinin düşmesine neden olduğu bilgisi edinilmiştir. Şirince köyüne ziyaret amaçlı gelen yabancı turistler genelde tur otobüsleri ille gelmektedir. Ancak yerli turistlerin önemli bir kısmı özel araçları ile gelmekte bu durum Şirince'de otopark vb. sorunlara neden olurken bir yandan da toplu taşıma arzının oluşmasına engel olmaktadır. Şirince nüfusunun toplu taşıma için uygun hacim ve yeterlilikte olmaması toplu taşıma arzının gelişmesini engellemiştir. Şirince yerli halkının büyük çoğunluğu Selçuk'ta konaklamakta ve özel araçlarıyla ulaşımlarını sağlamaktadırlar. Köyde minibüs kullanımı yaz aylarında yarım saate bir yapılırken kış aylarında saat başı yapılmaktadır bu da özel araç kullanımını tetikleyen önemli sebeplerden birisidir.

\subsection{Yaya Erişimi}

Şirince'de yolların oldukça dar olması, araçların ve yayaların erişiminde sorunlara neden olmaktadır. Yaya öncelikli bir sokağı yaya ile birlikte taşıtın da kullanması yayalar için tehdit oluşturmakta, araçların yaya öncelikli mekânlara işgalinin olması yaya güvenliğini tehlikeye atmaktadır. Şirince'de tarım sektörü ekonomideki en büyük paya sahiptir. Tarımsal faaliyet amaçlı araçların yaya ulaşımına uygun olan mekânlarda etkin olması ulaşım sorunları arasındadır. Kış mevsiminde Arnavut kaldırımlı sokakların don olayından dolayı kayması yaya güvenliği için risk oluşturmaktadır. Şirince'de yaşayan nüfusun yetersiz olması gece yayaların sokaklarda dolaşımını emniyetsiz hale getirmektedir. Aydınlatma elemanları yetersiz olup yolların bakımsız ve bozuk olması erişilebilirliği düşüren önemli faktörlerdendir. Bu iki 
durum yaya ve taşıt dolaşımını olumsuz yönde etkilemekte olup yürüme emniyetini zayıflatmaktadır. Köyün eğilimli bir yamaçta kurulması, yokuş ve merdivenlerin kontrolsüz olması yayaların sokaklarda dolaşımını zorlaştırmaktadır.

\subsection{Bisiklet ve motosiklet erişimi}

Sakin yerleşmeyi tercih eden insanların bölgeyi tercih etmelerinde etkili olan sebep Şirince köyünün taşıt ve motosiklet gürültüsünden uzak olmasıdır. Yollarının çok dar, virajlı olması aynı zamanda Arnavut kaldırım ile toprak yollardan oluşan yol üst yapısı motosiklet erişilebilirliğini azaltmaktadır. Şirince çok eğimli bir alanda kurulduğu için bisiklet erişimi de zordur. Bisiklet ulaşımını özendirici faaliyetler yapılmamaktadır.

\subsection{Arazi kullanım ve ulaşım arasındaki ilişki}

Kentsel ulaşım sorunlarının ortaya çıkmasının önemli nedenlerinden birisi planlama aşamalarında ulaşım ile arazi kullanımı arasındaki ilişkinin yeterli düzeyde incelenmemesinden kaynaklanmaktadır. Bu sebeple kentsel ulaşım ve arazi kullanım arasındaki ilişkinin incelenmesi bağlamında Şirince arazi kullanım analizi yapılmıştır. Konut kullanımı, ticaret alanları, kamusal alanlar, yeşil alanlar ve diğerleri kullanım türleriyle ulaşım ilişkilendirilmiştir. Şekil 9'da Şirince'nin arazi kullanım haritası verilmiştir.

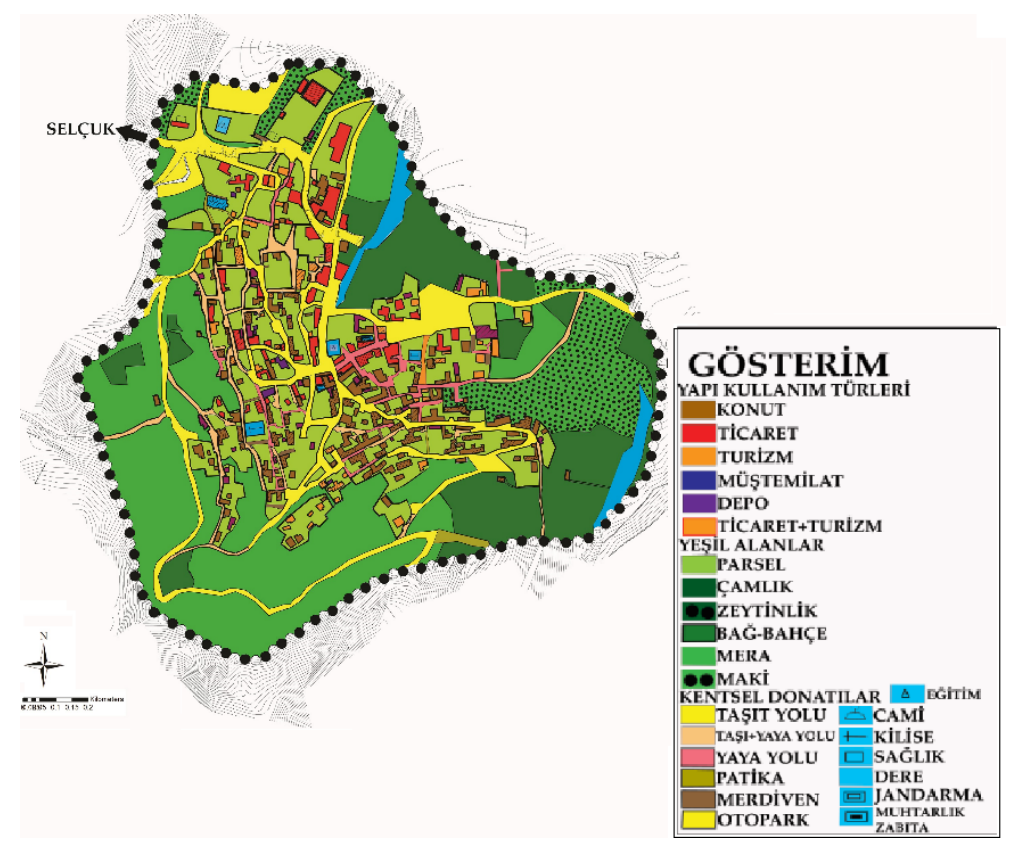

Şekil 9. Arazi kullanım haritası (Pamukkale Üniversitesi, 2016).

Kent içi trafiği belirleyen ana etken, kentin gelişme biçimini ifade eden makro-form ve sosyal, demografik ve sektörel yapı ile bağlantılı nüfusun günlük yer değiştirmesidir. Şirince'nin gelişmesinin kısıtlayan doğal (dere, dağ, orman...) ve yapay (yol vb.) eşikler kentin gelişme yönünü etkileyerek kentin makro-formunun oluşumunda belirleyici olmuşlardır. Doğal ve yapay eşikler kentin gelişme yönünde etkili oldukları için bahçelerin, doğal ortama ve ekolojik alanlara yayılımı kısıtlamışlar, bu yönde gelişimi engellemişlerdir. Bu da Şirince'nin özgün değerinin bir nevi korunmasına destek olmaktadır. Şirince'nin özgün dokusunun korunması için köy doğal ve kentsel sit alanı ilan edilmiş olup tescilli yapıları oldukça fazladır. Özellikle de köy meydanı olarak adlandırılan ticaret koridorunun ve çarşının bulunduğu alanlarda farklı kullanım türleri(konut, ticaret, turizm, kamusal yapı, depo vb.) tescillenmiştir. Konut alanları ise genel olarak 
tescilli yapılardan oluşmaktadır. Ayrıca köy meydanında ve bu alanın güneyinde konut alanları yoğunlaşmış olup ulaşım aksları bu akslarda yönelim göstermektedir. Barınma alanları haricinde rekreasyon, ticaret ve kamusal alanlar genel olarak ulaşımın kolay olduğu erişilebilirliğin kolay sağlandığı alanlarda yoğunlaşmışır. Şirince'de konut alanlarının genel olarak alanın güneyinde yoğunlaştığı görülmektedir. Ticaret alanlarının ise çarşıya uzanan yol boyunca yoğunlaştı̆̆ı görülmektedir. Konut alanlarının yoğunlaştığı alandan köyün Selçuk yönüne uzanan aksı doğrultusunda ticaret koridoru oluştuğu görülmektedir. Şirince köyü sit alanı içerisinde olduğu için turizm talebine yönelik konaklama alanları(pansiyon, motel vb.)yapılması yasaktır. Bu sebeple konut alanları Konut+Turizm alanlarına dönüştürülmüştür. Alt katta ticaret vb. faaliyetler yapılmakta üst katlarda ise konaklama yapılmaktadır. $\mathrm{Bu}$ alanların yol boyunca yayılmasının sebebi ulaşım ve erişim olanaklarının yeterli olmasından kaynaklanmaktadır. Ulaşılabilirliğin kısıtı olduğu ya da olmadığı alanlarda bu faaliyetler oldukça zayıftır. Kamusal alanların(eğitim, sağlık, jandarma, muhtarlık-zabıta vb.) ise ticaret alanlarının yoğun olarak bulunduğu kentin meydanı olarak kullanılan ulaşım ve erişim olanaklarının yeterli olduğu alanda yoğunlaştı̆̆ı analizler sonucu elde edilmiştir. Şekil 9'da kentsel doku analizi verilmiştir.

\section{ULAȘIM STRATEJi ve İLKELERININ BELIRLENMESI}

Ulaşım sorunlarının çözülmesi, bölgeye bütüncül bir bakış açısı ile yaklaşım getiren bir planlama anlayışı ile mümkündür. Bu doğrultuda Şirince'de etkin bir turizm planlama ve kırsal miras koruma stratejisi geliştirilmelidir. Kırsal koruma stratejisi mekânsal stratejiler, ekolojik stratejiler, ekonomik stratejiler, sosyal-kültürel stratejiler ve kurumsal stratejiler kapsamında ele alınabilir (Özcan, 2017).

Tarihi sokaklar atlı ve yaya ulaşımına uygun olarak düşünülmüş ve tasarlanmış organik dokuyu yansıtan alanlardır. Ancak giderek değişen ve dönüşen toplumsal, sosyo- kültürel, ekonomik, sektörel vb. yapılar, araç sahipliğinin artması ve talepler tarihi çevrelerin günümüz modern ulaşım sistemleri ile etkileşime girmesini gerektirmiştir. Bazı yerleşmelerde tarihi dokunun korunması bağlamında işlevsel dönüşümler yapılmış bu yapılan dönüşümler daha çok nüfusun bu alanlarda yığılmasına neden olmuştur. Bu sebeple ulaşım sorunu içinden çıkılmaz bir hal almıştır. Bu sorunların çözümü için yollar genişletilmiş, köprüler geçitler yapılmış sorun çözülmeye çalışılırken daha da içinden çıkılmaz bir hale getirilmiştir. Şirince'de yaşanan/yaşanmakta olan dönüşümün yönetilebilmesi ve ulaşım bağlamında sürdürülebilirliğin sağlanması için aşağıdaki ilkesel yaklaşımlar ve stratejiler üretilmiştir.

\section{Şirince'nin ulaşım planlamasına yönelik stratejiler ve ilkeler}

- Bölgeye olan erişilebilirliğin arttırılması için topoğrafik engellerin aşılmasında çeşitli teknolojik olanaklardan yararlanılması gereklidir. Selçuk'tan Şirince'ye ulaşım sağlanırken, özellikle tur otobüsleri için yolun çok virajı ve dar olması önemli trafik güvenliği sorunları yaratmaktadır. Şirince köyü tepede kalan bir yerleşkedir. Bu sorunun çözümü amacıyla; Selçuk- Şirince arası ulaşımı sağlayan karayolu, tepenin altından belirli hatları tünelle geçebilir.

Ulaşım tür ve hatlarındaki gereklilikler turizm potansiyellerine hizmet edecek şekilde tasarlanmalıdır. Tepeye çıkan bir asansör planlanarak; asansör 30-40 kişilik vagonu ile turistleri taşıyan bir turistik erişim hattı olarak değerlendirilebilir. Asansör ile tepeye çıkarken görsel açıdan güçlü manzara seyir noktaları oluşacaktır. Örnek olarak Şirince'de turistleri karşılayan ana ticaret aksının başından önemli çekim noktaları olan St. Jean ve Demetrius Kliselerinin olduğu topoğrafik olarak üst bölgelere doğru turistik amaçlı ulaşım türleri uygulanma potansiyeli mevcuttur.

- $\quad$ Şirince köyü tarihi sokak dokusunu korumak amacıyla tarihi yerleşim yeri olan köy dükkânların servis alması, ambulans girişleri ve acil durumlar değerlendirilerek yayalaştırılabilir. Köye sadece toplu 
taşıma veya özel araçlarla gelip bir noktaya kadar ulaşım sağlanıp daha sonra organik dokuya yaya ya da basit bir taşıma sistemi ile girilmelidir. Böyleye Şirince'nin organik sokak dokusu algısı ve doğal yol üst yapısı korunmuş olacaktır.

- Doğal doku ile ekolojik yaşamı korumak ve yaya erişim sorunlarına çözümler geliştirmek amacıyla tarihi dokuda yeşil koridorlar tasarlanmalıdır. Tasarlanan bu koridorlar ile yayalar ve organik sokak dokusu taşıt trafiğinden arındırılabilir.

- $\quad$ Şirince'nin Sokak karakteri Müze Kent vizyonu ile korunabilir. Tur otobüsleri ile gelen turistler belli bir noktaya kadar otobüs ile gelip daha sonra yaya devam ederek belli bir ücret karşıllğı köyü gezebilir. Evlerin önünde açılan sergilerden alışveriş yapıp geleneksel lezzetleri tatma imkânı bulabilirler. Bu konsept altında trafik yayalaştırılacağı ve kent açık hava müzesi olarak değerlendirilmiş olacağı için pek çok ulaşım kaynaklı sorun ortadan kalkacaktır.

- $\quad$ Bölgedeki turizm talebinin karşılanması için otopark kapasitesinin arttırılması gerekmektedir. Bu artış bölgede ekolojik açından değerli olan flora ve faunaya zarar vermeden sağlanmalıdır. Parklanma teknolojilerinden yararlanarak ve otopark yönetimi (parking management) stratejileri ile parklanma kapasitesi arttırılabilir. Mevcut otopark tesislerinde asansörlü otopark sistemleri değerlendirilmelidir. Böylece alan artışı olmadan kapasitenin arttırılması sağlanabilir.

- $\quad$ Şirince'de hizmet verebilecek alternatif ulaşım sistemleri kurulmalıdır. Özellikle zorlu topografyayı aşabilecek ve erişimi kolaylaştıracak ulaşım türleri dikkate alınmalıdır. Ulaşımı kolaylaştıracak teleferik, köprü, vagon, ring, asansör, elektrikli merdivenler ve benzer ulaşım vasıtaları/araçları da değerlendirilmelidir.

- $\quad$ Şirince'yi sadece tek başına bir yerleşme olarak değil yakınındaki ve etkisi alanında olduğu değişik ölçeklerdeki kentlerle birlikte ele almak gerekmektedir. Bu durumda bölgedeki kontrolsüz talebin kontrol altına alınması, Selçuk ve Kuşadası ile ilişkilerinin düzenlenmesi gerekmektedir. Özellikle bölgeye gelen tur otobüslerinin saatlerinin trafik etki değerlendirme analizi yapılarak ziyaret saatleri planlanmalı ve zamana yayılmalıdır.

- $\quad$ Tarihi alanlarda en önemli mekânsal etkileşim türü konut- sokak etkileşimidir. Sokak ve evler arasındaki etkileşimin her boyutu kıymetli ve korunmaya değerdir. Bu nedenle kentte yapılacak her türlü ulaşım ve arazi kullanım müdahalesinde bu organik ilişkinin korunması öncelikli olmalıdır.

- Yasal düzenlemelerle bahçe, yol ve kaldırım gibi her türlü düzenlemede doku içerisindeki bütünlük gözetilmelidir. Koruma amaçı Nazım İmar Planı Plan Notları ile bölgenin organik dokusuna aykırı dolu-boşluk oranlarının engellenerek dokunun korunması, parsel-yapı ve parsel-sokak ilişkisinin geleneksel özelliği koruyacak şekilde planlanması sağlanmalıdır. Malzeme seçiminde geleneksel dokuyu uyumlu malzemeler seçilmeli ve uyumlu şekilde eklemlenmelidir.

- Toplu Taşıma talebi oluşmadığı için gelişemeyen toplu taşıma arzı talep kışkırtması ile arttırılabilir. Arttırılan ulaşım ve erişim olanakları, reklamasyon, bilgilendirme ve yönlendirme ile insanların zamanla bölgeye ulaşımda toplu taşımayı tercih etmelerini sağlayacaktır. Etkin bir organizasyon ile seyahat süresi kısaltılmalı, sefer sıklıkları arttırılmalı, araçların konforları yükseltilmelidir. Nitelikli bir tanıtım ile güçlendirilen sistem toplu taşıma talebini kışkırtacaktır.

- $\quad$ Şirince'deki yol üst yapısı, topoğrafik yapı, doğal ve yapay eşikler, bisiklet ve motosiklet erişimini kent içinde zorlaştırmaktadır. Fakat bu ulaşım türleri Şirince'ye ulaşımda kullanılabilir türleridir. Bu türlerin artması otopark talebini azaltacaktır. Bu nedenle bisiklet ve motosiklet kullanımını özendirici altyapı olanakları ve düzenlemeler yaratılmalıdır. 


\section{SONUÇ}

Bu çalışmada, tarihi çevrelerde sokak dokularını korumak ve bu dokularda yaşanan ulaşım sorunlarına çözüm bulmak amacıyla bazı çözümler ve stratejiler öngörülmüştür.

Tarihi dokular ve gelişme alanlarının birbirinden ayrı değil bütüncül düşünülmelidir. Doku içerisindeki herhangi bir sorunu çözmek için dokunun sadece yakın çevresinin değerlendirilip incelenmesi yeterli olmamaktadır.

Tarihi dokularda sokakları ilginç ve korunması gerekli kılan özellik, dokudaki yapılar ve kullanıcıları arasındaki ilişkidir. Bu ilişki tarihi sokak karakterinin oluşmasını sağlamıştır. Bu alanlarda yaşanan sorunlara çözümler üretilirken oldukça sade, dokuyla uyumlu öneriler geliştirilmeli ve gelişme alanları da dokuyla birlikte ele alınmalıdır. Yeni yapılaşma alanları için kullanılan malzeme tarihi dokuda kullanılan malzemeler ile uyumlu olmalıdır. Özel taşıtlar tarihi dokulara girmemeli, dokunun dış çeperinde bırakılmalıdır veya taşıt sadece servis amaçlı kullanılan belli bir noktaya kadar ulaşımı sağlayan araç olarak değerlendirilmelidir. Araçların doku ile etkileşimi zaman ve araç türü açısından kısıtlanmalıdır. Taşıt ile yaya ulaşımını ayıran alt yollar bu iki nokta arasındaki ilişkiyi koparan değil daha da güçlü kılıp birleştiren seviyede olmalıdır. Taşıta göre mekân oluşmamalıdır.

\section{TEŞEKKÜRLER}

Bu çalışma, Dürdane DEMiRAY'ın değerli katkıları ile hazırlanmış olup Pamukkale Üniversitesi, Şehir ve Bölge Planlama Bölümü, 2015-2016 Bahar Yarıyılı Stüdyo-2 Dersi kapsamında yapılan atölye çalışmalarının bir bölümünden yararlanılarak oluşturulmuştur.

\section{KAYNAKÇA / REFERENCES}

Aru, K. A. (1998). Türk Kenti; Yapı Endüstri Merkezi Yayınları sf.13.

Avcıoğlu, S. (2009). Tarihi Çevrelerde Kentsel Yenileme Eğilimleri: Tuzla Köyiçi Örneği. Y. Lisans Tezi. Gebze İleri teknoloji Enstitüsü Mühendislik ve Fen bilimleri Enstitüsü. https://www.researchgate.net/publication/317067041

Beker, O. (2002). Kentsel Sit Alanı Koruma Amaçı Imar Planı Araştırma Raporu. Selçuk Belediyesi.

Güreşçi, E. (2011). Yoğun ulaşım talebi içeren ve güçlü bir tarihi çevre niteliği olan Selçuk-Şirince Köyü. Sosyo-ekonomi/2011-MI/11MI07.

Gulhan, G. (2007). Doğal ve Kültürel Değerlere Sahip Alanlarda Turizm Potansiyellerinin Değerlendirilmesi: Selçuk Örneği. Lisansüstü Tezi. Dokuz Eylül Üniversitesi, Fen Bilimleri Enstitüsü.

Gulhan, G. (2018). Kişisel Fotoğraf Arşivi.

Kılıçarslan, Ç.; Malkoç, E.; Özkan, M. B.; Tunçalp, G. \& Aydın, A. O. (2012). Kentsel Sit Yerleşimlerinde Dış Mekân Yaşantısının Değerlendirilmesi: Şirince Köyü, Selçuk. Ege Üniversitesi Ziraat Fakültesi Dergisi, 49 (3), 265-274.

Köşklük Kaya, N. (2012). Şirince Köyü Örneğinde Kırsal Mimari Mirasın Kırsal Turizmin Gelişmesine Katkısının TartışıIması. KMÜ Sosyal ve Ekonomik Araştırmalar Dergisi, 14 (22), 119-123.

Özcan, K. (2017). Kırsal Miras Koruma Stratejisi Sandıma Köyü, Bodrum. Milli Folklor. Sayı:113. 
Pamukkale Üniversitesi (2016). Mimarlık ve Tasarım Fakültesi, Şehir ve Bölge Planlama Bölümü, Stüdyo 2, 2015-2016 Atölye Çalışmaları.

Semenderoğlu, A. \& Oban, R. (2007). Şirince'de Kültürel Turizmin Gelişimi. Dokuz Eylül Üniversitesi Buca Eğitim Fakültesi,22,174-184.

Selçuk Belediyesi Resmi Web Sitesi (2018). http://www.selcuk.bel.tr/icerik/102/4408/sirinceyikemeralti-havasindan-cikaracagiz.aspx

Şirince Fotoğrafları (2018). http://www.yollardan.com/galleries/sirince-fotograflari/

Türkiye Ulaşım ve İletişim Stratejisi (2018). T.C. Ulaştırma Bakanlığı. Erişim Adresi: http://www.sp.gov.tr

Ongun, U. \& Gövdere, B. (2015). Kırsal Turizmin Kırsal Kalkınmaya Etkisi: Şirince Örneği. Uluslararası Sosyal ve Ekonomik Bilimler Dergisi, International Journal of Social and Economic Sciences 5 (2): 4655, 2015.

Uzun, H. (2010). Tarihi Kent Merkezleri Ulaşım Iliş̧kilerinin Koruma Bağlamında Değerlendirilmesi Izmir Tarihi Kent Merkezi Örneği. Yüksek Lisans Tezi, iTÜ Fen Bilimleri Enstitüsü.

Yaşlıca, E.; Şenlier, N.; Çalışır, S. \& Hovardaoğlu, O. (2017). Tarihi Kentsel Dokularda Yaşam Kalitesinin Arttırılmasında Ulaşım Sorunu iç̧in Çözüm Önerileri. Erişim Adresi: http://www.trafik.gov.tr/SiteAssets/Yayinlar/Bildiriler/pdf/A2-24.pdf 